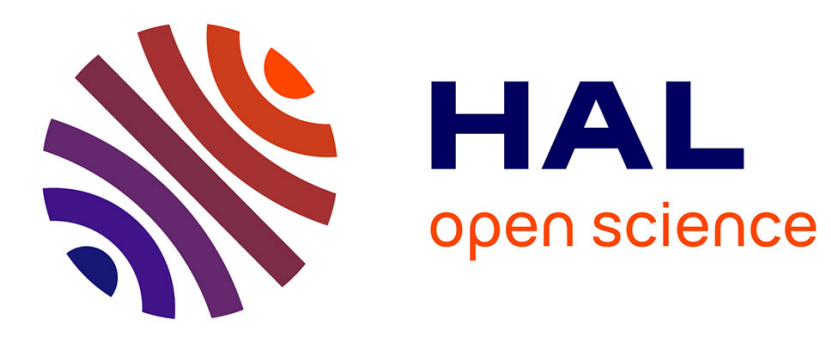

\title{
Trends in response rate and survival in small-cell lung cancer patients between 1997 and 2017
}

Mickaël Lattuca-Truc, Jean-François Timsit, Matteo Giaj Levra, Stéphane Ruckly, Julie Villa, Isabelle Dumas, Julian Pinsolle, Léonie Ferrer, Pascale Guillem, Denis Moro-Sibilot, et al.

\section{To cite this version:}

Mickaël Lattuca-Truc, Jean-François Timsit, Matteo Giaj Levra, Stéphane Ruckly, Julie Villa, et al.. Trends in response rate and survival in small-cell lung cancer patients between 1997 and 2017. Lung Cancer, 2019, 131, pp.122 - 127. 10.1016/j.lungcan.2019.03.028 . hal-03485105

\section{HAL Id: hal-03485105 https://hal.science/hal-03485105}

Submitted on 20 Dec 2021

HAL is a multi-disciplinary open access archive for the deposit and dissemination of scientific research documents, whether they are published or not. The documents may come from teaching and research institutions in France or abroad, or from public or private research centers.
L'archive ouverte pluridisciplinaire HAL, est destinée au dépôt et à la diffusion de documents scientifiques de niveau recherche, publiés ou non, émanant des établissements d'enseignement et de recherche français ou étrangers, des laboratoires publics ou privés.

\section{(ㅇ)(1) $\$$}

Distributed under a Creative Commons Attribution - NonCommercial| 4.0 International 


\section{Trends in Response Rate and Survival in Small-Cell Lung}

\section{Cancer Patients Between 1997 and 2017}

Mickaël Lattuca-Truc, MD, ${ }^{\mathrm{a}}$ Jean-François Timsit, MD, PhD, ${ }^{\mathrm{b}}$ Matteo Giaj Levra, MD, PhD, ${ }^{\mathrm{a}}$

Stéphane Ruckly, MSc, ${ }^{\mathrm{b}}$ Julie Villa, MD, ${ }^{\mathrm{c}}$ Isabelle Dumas, MD, ${ }^{\mathrm{d}}$ Julian Pinsolle, MD, ${ }^{\mathrm{a}}$ Léonie

Ferrer, MD, ${ }^{\mathrm{a}}$ Pascale Guillem, MD,${ }^{\mathrm{d}}$ Denis Moro-Sibilot, MD, ${ }^{\mathrm{a}}$ Anne-Claire Toffart, MD, PhD, ${ }^{\mathrm{a}, \mathrm{e}, *}$

for the Multidisciplinary Thoracic Oncology Group, Grenoble University Hospital, France

${ }^{a}$ Thoracic Oncology Unit, Grenoble-Alpes University Hospital, Grenoble, France

${ }^{b}$ Department of Biostatistics, OUTCOMEREA TM, Bobigny, France

${ }^{c}$ Radiotherapy Unit, Grenoble-Alpes University Hospital, Grenoble, France

${ }^{d}$ Cancer Coordination Center, Grenoble-Alpes University Hospital, Grenoble, France

${ }^{e}$ Institute for Advanced Biosciences, Grenoble, France

*Corresponding author.

Address for correspondence: Anne-Claire Toffart, UM Oncologie Thoracique, Pôle Thorax et Vaisseaux, Centre Hospitalier Universitaire A Michallon, BP217, 38043 Grenoble Cedex 9, France.

Tel.: +33 476765 467; Fax: +33 476768 855; E-mail: AToffart@ chu-grenoble.fr 


\section{ABSTRACT}

Introduction: Median survival of small-cell lung cancer (SCLC) patients is usually around 1 year. The advent of new drugs may have slightly improved their prognosis. We aimed to assess whether SCLC response to chemotherapy and survival had changed over time.

Methods: Consecutive SCLC patients were included at Grenoble University Hospital, France. We compared the patients' characteristics, response to chemotherapy and survival between 1997-2009 (period 1) and 2010-2017 (period 2).

Results: A total of 529 patients were identified, of whom 498 received a first line of chemotherapy and 279 a second line. The majority $(n=290,58 \%)$ had extensive disease. The objective response rate (ORR) to first-line chemotherapy in metastatic patients was $63 \%$ in period 1 and $62 \%$ in period 2; the ORRs to second-line chemotherapy were 39\% and 29\%, respectively. Median overall survival from first-line chemotherapy was 13.2 months (interquartile range [IQR]: 7.4-24.4) in period 1 and 11.2 months (IQR: 7.1-21.2) in period 2. Mortality in these two periods did not differ significantly even after adjustment for prognostic factors (hazard ratio $[\mathrm{HR}]=0.82,95 \%$ confidence interval $[\mathrm{CI}]$ 0.66-1.00). The factors independently associated with death were cardiovascular comorbidities $(\mathrm{HR}=1.28$ [95\%CI 1.05-1.55]), liver comorbidities (HR=1.31 [95\%CI 1.03-1.65]), poor ECOG performance status (3-4 vs. $0-1, \mathrm{HR}=2.45$ [95\%CI 1.83-3.30]) and extensive disease $(\mathrm{HR}=2.69$ [95\%CI 2.18-3.33]).

Conclusions: Since 1997, there has been no improvement in the survival or response rate to chemotherapy of SCLC patients. There is a desperate need for new approaches in this setting.

Keywords: Small-cell lung cancer; Chemotherapy; Response; Survival 


\section{Introduction}

Small-cell lung cancer (SCLC) represents 13 to $20 \%$ of lung cancer [1, 3]. Tobacco consumption is the main risk factor for this disease. While the proportion diagnosed with SCLC has declined from approximately 20 to 13\% in Europe [3], it has remained stable in the United States of America (USA) [2, 3]. SCLC is often considered an incurable disease, with median survival being shorter than non-small cell lung cancer and less than 12 months at any stage [3]. In the last two decades, there has been no dramatic breakthrough in the clinical care of SCLC and survival has remained poor [3]. Schabath et al. [4] identified an increase in the median survival time of treated SCLC from 11.3 to 15.2 months. These two studies included patients up to 2010 and no data is available for subsequent patients with SCLC.

Two forms of the disease are distinguished in the TNM classification, namely extensive and limited SCLC [5]. The improvement of imaging, particularly with positron emission tomography (PET) [6], has made a better approach to the disease possible because all tumor sites can be characterized. This has caused a decrease in the proportion of cases with limited SCLC [7]. Treatment is adapted to each patient depending on whether they have extensive or limited disease. Platinum-based chemotherapy $(\mathrm{CT})$ remains the cornerstone of first-line treatment [8], and it is combined with thoracic radiotherapy in limited disease [9]. All limited cases should be considered for prophylactic cranial irradiation (PCI) [10] if they respond to initial treatment. For extensive cases, PCI should be discussed if there is disease stability or a disease response at the end of treatment, since it could prevent the development of brain metastases and improve patient survival [10].

Most patients relapse and second-line treatment depends on sensitivity to the first-line CT. Patients with sensitive relapse may derive benefit from a re-initiation of the first-line regimen [9]. Only topotecan is recommended in the second line [11]. Cyclophosphamide, doxorubicin and vincristine $(\mathrm{CAV})$ is another option. 
However, the advent of new regimens and the impact of supportive treatments may have slightly improved the prognosis of these patients. The aim of this study was to compare response to CT in two distinct periods between 1997 and 2017.

\section{Material and Methods}

\subsection{Study Design and Patients}

All SCLC patients discussed during weekly thoracic oncology multidisciplinary team meetings at Grenoble Alpes university hospital, France, were selected. Any who required multidisciplinary expertise were presented. Metastatic cases have to be treated according to the guidelines only. This data has been entered into a database since 1980. This paper followed on from an initial analysis of 300 SCLC patients discussed between 1997 and 2009 [12]. We added patients discussed during our team meetings between 2010 and 2017. All patients who received at least one line of CT were included, those receiving supportive care only at diagnosis were excluded from the analysis. The study obtained ethical approval on September 12, 2018 (CECIC Rhône-Alpes-Auvergne, Clermont-Ferrand, IRB 5891). An information letter was sent to each living patient, while we obtained an exemption from the obligation to inform deceased patients (from the CNIL, the French data protection agency).

Our primary objective was to identify the factors associated with a response to first- and second-line CT. The secondary objectives were to compare survival between period 1 (1997-2009) and period 2 (2010-2017) and to identify prognostic factors at the beginning of first- and second-line treatment.

\subsection{Data Collection}

The following clinical data were collected at the time of diagnosis: sex, age, weight loss, Eastern Cooperative Oncology Group (ECOG) performance status (PS) [13], smoking history and cancer characteristics (histology, stage, and related paraneoplastic syndromes). Each antineoplastic treatment (CT, radiotherapy, and surgery) and the response to each treatment line were reported. 
Follow-up was completed for all patients in December 2017 using our hospital medical records or a call to the place of birth.

Using the response to treatment (RECIST criteria [14]) at 3 months after the end of the first CT, we classified patients into three categories: "sensitive" if an objective response (a partial or complete response) was observed at 3 months, "resistant" if an initial objective response was observed but relapse occurred before 3 months, and "refractory" if no response was observed or progression occurred during treatment [15].

\subsection{Statistical Analysis}

Data were expressed as number (and percentage) for qualitative variables and median (and interquartile range $[\mathrm{IQR}]$ ) for quantitative variables and were compared between the two period groups using chi-squared or Mann-Whitney tests, as appropriate.

The potential risk factors associated with survival from the beginning of first- and second-line treatment were estimated using univariate Cox models. Multivariate Cox models adjusted for significant variables were computed with stepwise selection. We decided to stop the analyses after the second line because of limited patient numbers. For the multivariate models, missing data was imputed into the model.

All tests were two-sided, and $P$ values $<0.05$ were considered statistically significant. All statistical analyses were performed using SAS 9.4 (SAS Institute, Cary, NC, USA).

\section{Results}

\subsection{Patient Characteristics and Anticancer Treatment}

A total number of 529 patients were identified (Fig. 1). Of these, 498 received a first line of treatment (477 [96\%] with etoposide and platinum CT), 279 a second line (126 [45\%] with etoposide and platinum CT and 122 [44\%] with taxane-based CT), and 121 a third line. The patients' characteristics are shown in Table 1. Median age was 64 years (IQR: 56-71), 116 
(23\%) were women, and $208(42 \%)$ had limited-stage disease. The proportion of patients with weight loss of $\geq 10 \%$ at diagnosis was higher in period $2(n=50,28 \%)$ compared to period $1(n=50$, $18 \%)(p<0.01)$. Concomitant or sequential mediastinal radiotherapy was performed in $96 / 148(65 \%)$ limited SCLC patients in period 1 and in 41/60 (68\%) in period 2. In period 1, 81 (26\%) patients received PCI, as did $59(33 \%)$ in period 2. Some 28 patients underwent surgery, in most cases $(n=16 / 18,89 \%)$ before the diagnosis of SCLC. In the 10 remaining patients, the date of surgical resection was not available.

\subsection{Objective Response Rates According to the Line of Chemotherapy}

In metastatic patients, the objective response rates (ORRs) to first-line chemotherapy were $63 \%$ and $62 \%$ during periods 1 and 2, respectively (Table 1$)$. Most patients $(n=226,45 \%)$ were sensitive to first-line treatment, 121 (24\%) were resistant, and 109 (22\%) refractory. This response pattern was similar across the two periods. The ORRs to second-line treatment were $39 \%$ and $29 \%$ in periods 1 and 2, respectively, and those to third-line treatment were $19 \%$ and $20 \%$.

Among those patients sensitive to first-line treatment, 144 (64\%) were able to receive a second line with an ORR of 52\% (n=75), and $21(9 \%)$ were still responding at the time of data analyses. Among resistant patients, $81(67 \%)$ were able to receive a second line with an ORR of $20 \%(n=16)$. Among refractory patients, 53 (49\%) were able to receive a second line with an ORR of $13 \%(\mathrm{n}=37)$.

\subsection{Factors Associated with Survival}

Median overall survival from the beginning of treatment was 12.2 months (IQR: 7.2-22.5), 13.2 months in period 1 (IQR: 7.4-24.4) and 11.2 months in period 2 (IQR: 7.1-21.2) (Supplemental Table 1).

Univariate and multivariate survival analyses from the beginning of first-line CT are reported in Table 2. Mortality did not differ significantly across the two periods, even after adjustment for prognostic factors (hazard ratio $(\mathrm{HR})=0.82 ; 95 \%$ confidence interval $[\mathrm{CI}] 0.66-1.00)$. Factors 
independently associated with mortality were cardiovascular comorbidity (HR=1.28 [95\%CI 1.061.55]), liver comorbidity (HR=1.29 [95\%CI 1.02-1.63]), ECOG PS ( 2 vs. $0-1, \mathrm{HR}=1.35$ [95\%CI 1.08-1.68]; 3-4 vs. 0-1, HR=2.45 [95\%CI 1.83-3.30]), and extensive disease (HR=2.67 [95\%CI 2.17-3.29]). Figure 2 represents this Cox adjusted survival curve.

From the beginning of second-line CT (Supplemental Table 1), the factors independently associated with mortality were extensive disease at diagnosis ( $\mathrm{HR}=1.52$ [95\%CI 1.17-1.99]), sensitivity to first-line $\mathrm{CT}(\mathrm{HR}=1.74$ [95\%CI 1.17-2.61] and $\mathrm{HR}=1.67$ [95\%CI 1.19-2.35] for refractory $v$. sensitive and resistant $v s$. sensitive, respectively), ECOG PS $\geq 2$ at the beginning of second-line treatment $(\mathrm{HR}=2.6[95 \% \mathrm{CI} 2-3.4])$, and the $\mathrm{CT}$ agents used in the second line $(\mathrm{HR}=1.55$ [95\% CI 1.11-2.17] and $\mathrm{HR}=1.1$ [95\% CI 0.68-1.77] for taxane vs. etoposide CT and other vs. etoposide CT, respectively). Figure 3 represents this Cox adjusted survival curve according to sensitivity to firstline CT.

\subsection{Impact of Tobacco Use}

In this study, 448 patients were smokers, of whom 158 (34\%) were former smokers and $290(62 \%)$ were active smokers. Never-smokers had poorer survival (Supplemental Table 1) with their median survival being 8.3 months (IQR: 3.0-12.2], as against 12.3 months (6.5-24) for former smokers and 12.2 months (7.4-22.4) for active smokers.

\section{Discussion}

This study highlights the lack of improvement in response to CT and survival over the last two decades. No change in the CT agents used was observed. Etoposide and platinum remain the standard CT. In our center, we often used taxane CT in the second line even though this drug has never been registered for this setting.

The strength of this study was the variety of data recorded in a large number of patients, such as the ECOG PS at the beginning of each line of CT as well as the response thereto. But only the data of 
patients discussed at our weekly thoracic oncology multidisciplinary team meetings were reported. That explains why a large majority of patients received CT. Furthermore, this study was conducted in real life conditions, and so disease response was evaluated by the physicians in charge of the patients without external control. We were not able to specify which patients were staged by 18 fluoro-deoxyglucose (FDG)-PET, nor were we able to provide progression-free survival data for each line of CT.

Our patients had similar characteristics to those reported in the study by the French College of General Hospital Respiratory Physicians (KBP-2010-CPHG [16]). Namely, 23\% were women, median age was 65 years, the proportions of never, former, and active smokers were the same, 55 to $60 \%$ had an ECOG PS of $0-1$, and $70 \%$ had extensive disease. In other countries, some of these characteristics differ. In the United Kingdom [17] and the USA [4], women made up half of SCLC patients, and age at diagnosis was older (68 years). Interestingly, in the study by Schabath et al., half of patients had limited-stage disease in the $2000-8$ period. Two patients' characteristics significantly differed between the 2 studied periods. We observed more patients with weight loss of $\geq 10 \%$ at diagnosis in the period 2 , it could be due to a better nutritional evaluation over the last decade. Advances in imaging, as the systematic use of the 18-FDG-PET to confirm the absence of metastasis could explain that fewer patients had a localized disease in period 2.

Comorbidity among patients with SCLC is very common and has been increasing [18]. As in our study, Aarts et al. identified heart disease as having a negative prognostic effect on SCLC patients [18]. We also identify liver comorbidity as prognostic factor, but, to our knowledge, it is not describe in the literature. These results encourage identifying and stabilizing cardiac and liver comorbidities when starting chemotherapy in order to avoid more toxicity during the treatment. SCLC in never-smokers is an uncommon but highly aggressive disease. Never-smokers had clearly shorter survival (8.3 months vs. 12.3 months in former smokers and 12.2 months in active smokers). This survival data were similar to other studies, even in limited-stage disease [19]. 
In the SEER database, nearly half of SCLC patients were treated. Additional therapy beyond platinum CT was associated with survival benefit [20]. These results are consistent with ours. Khakwani et al. [17] observed an increase in the proportion of patients receiving both $\mathrm{CT}$ and radiotherapy each year (from 19 to $40 \%$ in limited disease and 9 to $21 \%$ in extensive disease between 2004 and 2011). As explained above, we are not able to provide this information.

In our study, the ORR to first-line CT (mostly etoposide and platinum) was $73 \%$. It was $67 \%$ in patients treated with cisplatin and $66 \%$ in those treated with carboplatin in the Rossi study [8]. Regarding sensitivity, $45 \%$ of our patients were platinum-sensitive, as in a previous study [21], and the ORRs to second- and third-line treatment were 36 and 19\%, respectively, without significant changes over time, while the disease control rates (DCRs) with second- and third-line treatment were 55 and 39\%, respectively. In a retrospective study [22] reporting disease response among 193 patients treated in the second line with platinum-based CT (mainly irinotecan or topotecan) or a single-agent therapy, the ORR was $25 \%$ in the combination group and $9 \%$ in the single-agent group, while in that study the DCRs were 65 and $35 \%$, respectively. In the second-line setting, the ORR to topotecan has been 24\%, and that to CAV 18\% [11]. In the study by Aktas et al. [21], the DCRs at first, second, and third-line CT were 92,68 , and 44\%, respectively. In contrast to our study, only $14 \%$ of primary-resistant patients were able to receive second-line CT.

From the beginning of second-line CT, we identified extensive disease at diagnosis, first-line sensitivity, a poor ECOG PS, and the second-line drugs used as being associated with mortality. These results are consistent with the study published by Song et al. [22] in which PS, recurrence type and further treatment were independently associated with survival on second-line treatment. An anti-PD1 (Nivolumab) was granted FDA approval in 2018 for the treatment of patients with SCLC with disease progression following platinum-based CT and one other line of therapy. Rovalpituzumab (in the first, second and third lines) [23] and Alisertib in combination with Nabpaclitaxel (in the second line) are new drugs being developed in SCLC. 


\section{Conclusions}

Since 1997, there has not been any improvement in response rates to CT or survival in SCLC patients. There is a desperate need for new approaches in this setting. Various ongoing clinical trials and the recent FDA approval of Nivolumab in SCLC are encouraging signs.

\section{Disclosure}

This work was supported by AbbVie.

Dr. LATTUCA TRUC has nothing to disclose.

Dr. TIMSIT has nothing to disclose.

Dr. GIAJ LEVRA reports non-financial support from MSD, personal fees from BMS, personal fees and non-financial support from Roche Hoffman, personal fees and non-financial support from Astra Zeneca, non-financial support from Boringer- Ingheleim, personal fees from Amgen outside the submitted work.

Dr. RUCKLY has nothing to disclose.

Dr. VILLA reports non-financial support from Pierre Fabre outside the submitted work.

Dr. DUMAS has nothing to disclose.

Dr. PINSOLLE has nothing to disclose.

Dr. FERRER reports non-financial support from Roche, non-financial support from Pfizer, nonfinancial support from BMS, non-financial support from Lilly pharma, non-financial support from Boehringer Ingelheim, outside the submitted work.

Dr. GUILLEM has nothing to disclose.

Dr. MORO-SIBILOT reports personal fees from roche, personal fees from ariad, personal fees from boehringer, personal fees from lilly, personal fees from pfizer, personal fees from novartis, personal fees from MSD, personal fees from BMS, personal fees from astra zeneca, personal fees from abbvie, personal fees from takeda outside the submitted work

Dr. TOFFART reports grants from Abbvie, during the conduct of the study; personal fees from 
MSD, personal fees and non-financial support from BMS, grants, personal fees and non-financial support from Roche Hoffman, personal fees and non-financial support from Astra Zeneca, personal fees and non-financial support from Boehringer- Ingelheim, grants and personal fees from Pfizer, personal fees from Vifor Pharma, personal fees from Lilly Pharma, non-financial support from Abbvie outside the submitted work.

\section{Acknowledgments}

We wish to thank Cremer Consulting SARL for English-language editing.

\section{References}

[1] Y. Nilssen, T.E. Strand, L. Fjellbirkeland, K. Bartnes, B. Møller, Lung cancer survival in Norway, 1997-2011: from nihilism to optimism, Eur. Respir. J. 47 (2016) 275-287. doi:10.1183/13993003.00650-2015.

[2] R. Meza, C. Meernik, J. Jeon, M.L. Cote, Lung Cancer Incidence Trends by Gender, Race and Histology in the United States, 1973-2010, PLOS ONE. 10 (2015) e0121323. doi:10.1371/journal.pone.0121323.

[3] M. Grivaux, B. Duvert, P. Ferrer-Lopez, S. Hominal, E. Goarant, A. Brichet-Martin, P. Romand, E. Fournier, B. Asselain, D. Debieuvre, [One-year survival improvement in lung cancer in France. Results of the prospective real life studies KBP-2000-CPHG and KBP-2010CPHG], Rev Pneumol Clin. 72 (2016) 163-170. doi:10.1016/j.pneumo.2016.02.002.

[4] M.B. Schabath, A. Nguyen, P. Wilson, K.R. Sommerer, Z.J. Thompson, A.A. Chiappori, Temporal trends from 1986 to 2008 in overall survival of small cell lung cancer patients, Lung Cancer. 86 (2014) 14-21. doi:10.1016/j.lungcan.2014.07.014.

[5] P. Goldstraw, K. Chansky, J. Crowley et al. The IASLC Lung Cancer Staging Project: Proposals for Revision of the TNM Stage Groupings in the Forthcoming (Eighth) Edition of the TNM Classification for Lung Cancer, Journal of Thoracic Oncology. 11 (2016) 39-51. doi:10.1016/j.jtho.2015.09.009.

[6] B.M. Fischer, J. Mortensen, The Future in Diagnosis and Staging of Lung Cancer: Positron Emission Tomography, Respiration. 73 (2006) 267-276. doi:10.1159/000092080.

[7] S. Bishnoi, K. Pittman, M. Colbeck, A. Townsend, J. Hardingham, S. Sukumaran, B. Hooper, M. Tuck, D. Roder, C. Luke, T. Price, Small cell lung cancer: patterns of care and their influence on survival - 25 years experience of a single Australian oncology unit, Asia Pac J Clin Oncol. 7 (2011) 252-257. doi:10.1111/j.1743-7563.2011.01426.x.

[8] A. Rossi, M. Di Maio, P. Chiodini, R.M. Rudd, H. Okamoto, D.V. Skarlos, M. Früh, W. Qian, T. Tamura, E. Samantas, T. Shibata, F. Perrone, C. Gallo, C. Gridelli, O. Martelli, S.-M. Lee, Carboplatin- or Cisplatin-Based Chemotherapy in First-Line Treatment of Small-Cell Lung Cancer: The COCIS Meta-Analysis of Individual Patient Data, Journal of Clinical Oncology. 30 (2012) 1692-1698. doi:10.1200/JCO.2011.40.4905.

[9] M. Früh, D. De Ruysscher, S. Popat, L. Crinò, S. Peters, E. Felip, ESMO Guidelines Working Group, Small-cell lung cancer (SCLC): ESMO Clinical Practice Guidelines for diagnosis, treatment and follow-up, Ann. Oncol. 24 Suppl 6 (2013) vi99-105. doi:10.1093/annonc/mdt178.

[10] B. Slotman, C. Faivre-Finn, G. Kramer, E. Rankin, M. Snee, M. Hatton, P. Postmus, L. 
Collette, E. Musat, S. Senan, Prophylactic Cranial Irradiation in Extensive Small-Cell Lung Cancer, New England Journal of Medicine. 357 (2007) 664-672.

doi:10.1056/NEJMoa071780.

[11] J. von Pawel, J.H. Schiller, F.A. Shepherd, S.Z. Fields, J.P. Kleisbauer, N.G. Chrysson, D.J. Stewart, P.I. Clark, M.C. Palmer, A. Depierre, J. Carmichael, J.B. Krebs, G. Ross, S.R. Lane, R. Gralla, Topotecan versus cyclophosphamide, doxorubicin, and vincristine for the treatment of recurrent small-cell lung cancer, J. Clin. Oncol. 17 (1999) 658-667. doi:10.1200/JCO.1999.17.2.658.

[12] H. Nagy-Mignotte, P. Guillem, L. Vignoud, M. Coudurier, A. Vesin, V. Bonneterre, A.-C. Toffart, L. Sakhri, C. Brambilla, E. Brambilla, J.-F. Timsit, D. Moro-Sibilot, Outcomes in recurrent small-cell lung cancer after one to four chemotherapy lines: A retrospective study of 300 patients, Lung Cancer. 78 (2012) 112-120. doi:10.1016/j.lungcan.2012.06.006.

[13] M.M. Oken, R.H. Creech, D.C. Tormey, J. Horton, T.E. Davis, E.T. McFadden, P.P. Carbone, Toxicity and response criteria of the Eastern Cooperative Oncology Group, Am. J. Clin. Oncol. 5 (1982) 649-655.

[14] E.A. Eisenhauer, P. Therasse, J. Bogaerts, L.H. Schwartz, D. Sargent, R. Ford, J. Dancey, S. Arbuck, S. Gwyther, M. Mooney, L. Rubinstein, L. Shankar, L. Dodd, R. Kaplan, D. Lacombe, J. Verweij, New response evaluation criteria in solid tumours: Revised RECIST guideline (version 1.1), European Journal of Cancer. 45 (2009) 228-247. doi:10.1016/j.ejca.2008.10.026.

[15] A. Kurup, N.H. Hanna, Treatment of small cell lung cancer, Critical Reviews in Oncology/Hematology. 52 (2004) 117-126. doi:10.1016/j.critrevonc.2004.08.005.

[16] C. Dayen, D. Debieuvre, O. Molinier, O. Raffy, F. Paganin, J. Virally, S. Larive, B. Desurmont-Salasc, M. Perrichon, F. Martin, M. Grivaux, New insights into stage and prognosis in small cell lung cancer: an analysis of 968 cases, Journal of Thoracic Disease. 9 (2017) 5101-5111. doi:10.21037/jtd.2017.11.52.

[17] A. Khakwani, A.L. Rich, L.J. Tata, H.A. Powell, R.A. Stanley, D.R. Baldwin, R.B. Hubbard, Small-Cell Lung Cancer in England: Trends in Survival and Chemotherapy Using the National Lung Cancer Audit, PLoS ONE. 9 (2014) e89426. doi:10.1371/journal.pone.0089426.

[18] M.J. Aarts, J.G. Aerts, B.E. van den Borne, B. Biesma, V.E.P.P. Lemmens, J.S. Kloover, Comorbidity in Patients With Small-Cell Lung Cancer: Trends and Prognostic Impact, Clinical Lung Cancer. 16 (2015) 282-291. doi:10.1016/j.cllc.2014.12.003.

[19] M. Torres-Durán, A. Ruano-Ravina, K.T. Kelsey, I. Parente-Lamelas, M. Provencio, V. LeiroFernández, J. Abal-Arca, C. Montero-Martínez, I. Vidal-Garcia, C. Pena, O. Castro-Añón, A. Golpe-Gómez, C. Martínez, R. Guzmán-Taveras, M.J. Mejuto-Martí, A. Fernández-Villar, J.M. Barros-Dios, Small cell lung cancer in never-smokers, European Respiratory Journal. 47 (2016) 947-953. doi:10.1183/13993003.01524-2015.

[20] M. Behera, C. Ragin, S. Kim, R.N. Pillai, Z. Chen, C.E. Steuer, N.F. Saba, C.P. Belani, F.R. Khuri, S.S. Ramalingam, T.K. Owonikoko, Trends, predictors, and impact of systemic chemotherapy in small cell lung cancer patients between 1985 and 2005: Small Cell Lung Cancer in SEER-Medicare, Cancer. 122 (2016) 50-60. doi:10.1002/cncr.29674.

[21] gokmen aktas, K. Tulay, mehmet emin kalender, alper sevinc, celaletdin camci, seval kul, Survival analysis in second-line and third-line chemotherapy with irinotecan followed by topotecan or topotecan followed by irinotecan for extensive-stage small-cell lung cancer patients: a single-center retrospective study, OncoTargets and Therapy. (2016) 1921. doi:10.2147/OTT.S101390.

[22] Z. Song, L. Shao, B. Lin, Y. Zhang, Single-agent chemotherapy compared with combination chemotherapy as second-line treatment in extensive-stage small cell lung cancer: a retrospective analysis, Clinical and Translational Oncology. 15 (2013) 843-848. doi:10.1007/s12094-013-1013-5.

[23] David Paul Carbone et al., Efficacy and safety of rovalpituzumab tesirine in patients With DLL3-expressing, $\geq$ 3rd line small cell lung cancer: Results from the phase 2 TRINITY study., 
(n.d.). 


\section{Figure Captions}

Figure 1. Flow chart of study patients.

Figure 2. Cox adjusted survival curve from the beginning of first-line chemotherapy. Adjustment was performed with variables associated with survival (Table 3): ECOG performance status, extensive versus limited disease, cardiovascular comorbidities, and liver comorbidities.

Figure 3. Cox adjusted survival curve from the beginning of second-line chemotherapy. Adjustment was performed with variables associated with survival (Table 3). 
$\mathrm{N}=477$ standerd $\mathrm{CI}$

$\mathrm{N}-1$ doxorubicin.

$\mathrm{N}=20$ other

$\mathrm{N}=126$ standard $\mathrm{CT}$

$\mathrm{N}=122$ taxane

$\mathrm{N}-17$ topotecan

$\mathrm{N}=9$ doxonubicin

N-5 other

$\mathrm{N}-60$ taxane

$\mathrm{N}=22$ topotecan

$\mathrm{N}-15$ standardCT

$\mathrm{N}=9$ doxonbicin

$\mathrm{N}=15$ other

$\mathrm{N}-17$ taxane

$\mathrm{N}=6$ topotecan

$\mathrm{N}=7$ doxonubicin

$\mathrm{N}-\mathrm{B}$ other

$\mathrm{N}=2$ standard $\mathrm{C} T$

$\mathrm{N}-1$ topotecan

$\mathrm{N}=1$ doxorubicin

$\mathrm{N}=3$ other
1 line $N-498$

290 extensive disease

208 limited disease

$\mathrm{N}=26$ paliative care

$\mathrm{N}=5$ lost to follow 4

\section{9 censored:}

$\mathrm{N}-137$ died of cancer

$\mathrm{N}=20$ died of ia trogenesis

$\mathrm{N}=26$ died of anothar disease

$\mathrm{N}=20$ alive with complete response

$\mathrm{N}=16$ alive

$2^{\mathrm{N}}$ line $\mathrm{N}=279$

168 extensive disease

111 limited disease
158 censored:

$\mathrm{N}=144$ died of cancer

$\mathrm{N}-4$ died of iatrogeresis

$\mathrm{N}=2$ died of another disease

$\mathrm{N}-2$ alive with completeresponse

$\mathrm{N}=6$ alive

83 censored:

$\mathrm{N}=74$ died of cancer

$\mathrm{N}=2$ died of iatrogenesia

$\mathrm{N}-2$ died of another disease

$\mathrm{N}=5$ alive with cancer

31 censored:

$\mathrm{N}=29$ died of cancer

$\mathrm{N}-2$ alive with cancer

15 extensive disease

23 limited disease

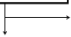

$5^{\text {th }}$ line $\mathrm{N}=7$

1 extensive disease

6 limited disease
- N-7 died of cancer 


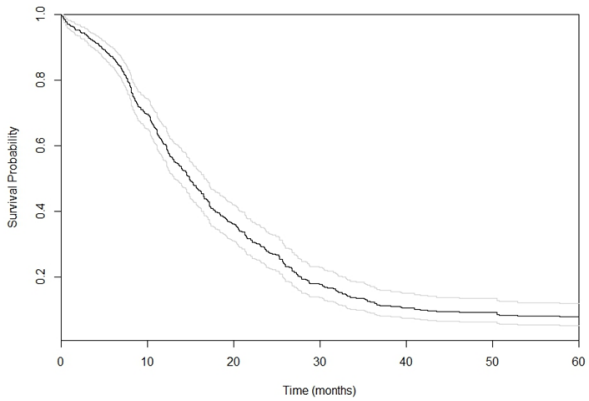




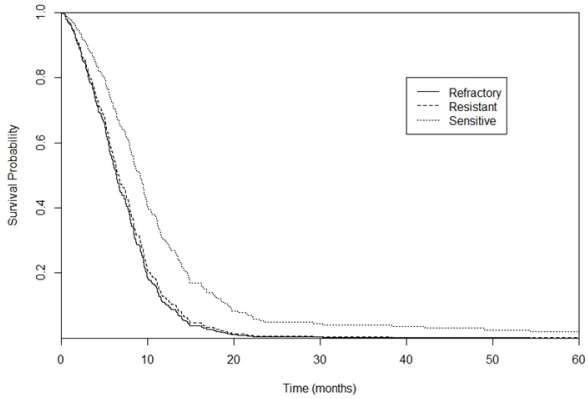


Table 1. Characteristics of Patients and Response to Chemotherapy according to Treatment Line

\begin{tabular}{|c|c|c|c|c|}
\hline Variable & $\begin{array}{l}\text { All patients } \\
\mathrm{N}=498\end{array}$ & $\begin{array}{l}\text { Diagnosis }<2010 \\
\mathrm{~N}=317\end{array}$ & $\begin{array}{l}\text { Diagnosis } \geq 2010 \\
N=181\end{array}$ & $P$ value \\
\hline \multicolumn{5}{|l|}{ Patient characteristics } \\
\hline Female & $116(23)$ & $73(23)$ & $43(24)$ & 0.85 \\
\hline Age (years) & $64[56-71]$ & $63[55-71]$ & $65[58-72]$ & 0.03 \\
\hline \multicolumn{5}{|l|}{ Smoking status (MD, $n=33$ ) } \\
\hline - Non-smoker & $17(4)$ & $10(4)$ & $7(4)$ & 0.23 \\
\hline - Former smoker & $158(34)$ & $89(31)$ & $69(39)$ & \\
\hline - Active smoker & $290(62)$ & $187(65)$ & $103(58)$ & \\
\hline \multicolumn{5}{|l|}{ Comorbidities } \\
\hline - Cardiovascular & $245(49)$ & $151(48)$ & $94(52)$ & 0.36 \\
\hline - Respiratory & $156(31)$ & $104(33)$ & $52(29)$ & 0.35 \\
\hline - Renal & $62(12)$ & $45(14)$ & $17(9)$ & 0.12 \\
\hline - Hepatic & $100(20)$ & $68(22)$ & $32(18)$ & 0.31 \\
\hline ECOG-PS (MD, n=2) & & & & 0.15 \\
\hline$-\quad 0-1$ & $278(56)$ & $181(58)$ & $97(54)$ & \\
\hline-2 & $150(30)$ & $98(31)$ & $52(29)$ & \\
\hline$-\quad 3-4$ & $68(14)$ & $36(11)$ & $32(18)$ & \\
\hline Weight loss $\geq 10 \%(\mathrm{MD}, \mathrm{n}=35)$ & $100(22)$ & $50(18)$ & $50(28)$ & $9.10^{-3}$ \\
\hline \multicolumn{5}{|l|}{ Cancer characteristics } \\
\hline Extensive disease & $290(58)$ & $169(53)$ & $121(67)$ & $3.10^{-3}$ \\
\hline \multicolumn{5}{|l|}{ Histology } \\
\hline - $\quad$ Pure SCLC & $453(91)$ & $289(91)$ & $164(91)$ & 0.83 \\
\hline - Combined SCLC & $45(9)$ & $28(9)$ & $17(9)$ & \\
\hline Paraneoplastic syndrome & & & & 0.70 \\
\hline - None & $424(85)$ & $270(85)$ & $154(85)$ & \\
\hline - Endocrinologic & $8(2)$ & $4(1)$ & $4(2)$ & \\
\hline - Other & $66(13)$ & $43(14)$ & $23(13)$ & \\
\hline \multicolumn{5}{|l|}{$1^{\text {st }}$ line concurrent treatment } \\
\hline Surgery & $28(6)$ & $24(8)$ & $4(2)$ & 0.01 \\
\hline \multicolumn{5}{|l|}{ Radiotherapy } \\
\hline - Mediastinal & $141(28)$ & $99(31)$ & $42(23)$ & 0.06 \\
\hline ED/LD & $4 / 137$ & $3 / 96$ & $1 / 41$ & \\
\hline - Cranial prophylaxis & $140(28)$ & $81(26)$ & $59(33)$ & 0.09 \\
\hline - Palliative & $65(13)$ & $42(13)$ & $23(13)$ & 0.86 \\
\hline \multicolumn{5}{|l|}{ Response to $1^{\text {st }}$ line CT } \\
\hline ORR (MD, n=13) & $352(73)$ & $228(74)$ & $124(71)$ & 0.52 \\
\hline ORR in LD (MD, $n=4)$ & $176 / 208(86)$ & $124 / 148(86)$ & $52 / 60(88)$ & 0.62 \\
\hline ORR in ED (MD, $n=9)$ & $176 / 290(63)$ & $104 / 169(63)$ & $72 / 121(62)$ & 0.87 \\
\hline Sensitivity (MD, $n=42)$ & & & & 0.70 \\
\hline - Sensitive & $226(45)$ & $150(47)$ & $76(42)$ & \\
\hline - Resistant & $121(24)$ & $74(24)$ & $47(26)$ & \\
\hline - Refractory & $109(22)$ & $68(22)$ & $41(23)$ & \\
\hline Response to $2^{\text {nd }}$ line CT & $\mathrm{N}=\mathbf{2 7 9}$ & $\mathrm{N}=179$ & $\mathrm{~N}=100$ & \\
\hline $\begin{array}{l}\text { ECOG-PS of } 0-1 \text { at the beginning } \\
\text { of } 2^{\text {nd }} \text { line }(M D, n=23)\end{array}$ & $136(53)$ & $88(56)$ & $48(48)$ & 0.19 \\
\hline $\begin{array}{l}\text { Time between the beginning of } 1^{\text {st }} \\
\text { and } 2^{\text {nd }} \text { lines }(M D, n=1)\end{array}$ & 9 [7-13] & $10[7-13]$ & $9[7-12]$ & 0.18 \\
\hline
\end{tabular}




\begin{tabular}{lllll}
\hline ORR & $99(36)$ & $70(39)$ & $29(29)$ & 0.09 \\
DCR & $154(55)$ & $99(55)$ & $55(55)$ & 0.96 \\
$\begin{array}{l}\text { Response to 3 } \\
\text { ECOG-PS of } \mathbf{0 - 1} \text { at the beginning } \\
\text { of } \mathbf{3}^{\text {rd }} \text { line (MD, n=11) }\end{array}$ & $\mathbf{N = 1 2 1}$ & $\mathbf{N = 8 1}$ & $\mathbf{N}=\mathbf{4 0}$ & \\
ORR & $51(46)$ & $34(49)$ & $17(43)$ & 0.54 \\
DCR & $23(19)$ & $15(19)$ & $8(20)$ & 0.85 \\
\hline
\end{tabular}

Data are expressed as median [IQR] for quantitative variables and as number (percentage) for qualitative variables.

DCR, disease control rate; ED, extensive disease; LD, limited disease; MD, missing data; ORR, objective response rate; PS, performance status; SCLC, small-cell lung cancer. 
Table 2. Univariate and Multivariate Analyses of Factors Associated with Mortality from First-Line Chemotherapy

\begin{tabular}{|c|c|c|}
\hline & $\begin{array}{l}\text { Univariate } \\
\text { analysis }\end{array}$ & $\begin{array}{l}\text { Multivariate } \\
\text { analysis }\end{array}$ \\
\hline Variable & HR [95\% CI $]$ & HR [95\% CI] \\
\hline 2010-2017 vs. 1997-2009 & $1.03[0.84-1.25]$ & $0.82[0.66-1.00]$ \\
\hline \multicolumn{3}{|l|}{ Baseline patient characteristics } \\
\hline Female vs. male & $0.80[0.64-1]$ & $\ldots$ \\
\hline Age $\geq 60$ years & $1.21[1-1.48]$ & $\ldots$ \\
\hline Cardiovascular comorbidity & $1.33[1.1-1.6]$ & $1.28[1.05-1.55]$ \\
\hline Respiratory comorbidity & $1.19[0.97-1.45]$ & $\ldots$ \\
\hline Renal comorbidity & $1.30[0.98-1.72]$ & $\ldots$ \\
\hline Hepatic comorbidity & $1.66[1.32-2.08]$ & $1.31[1.03-1.65]$ \\
\hline \multicolumn{3}{|l|}{ ECOG-PS (MD, $n=2)$} \\
\hline$-\quad 0-1$ & 1 & 1 \\
\hline-2 & $1.81[1.47-2.23]$ & $1.35[1.08-1.68]$ \\
\hline$-\quad 3-4$ & $3.40[2.57-4.50]$ & $2.45[1.83-3.30]$ \\
\hline Weight loss $\geq 10 \%(M D, n=35)$ & $1.70[1.34-2.15]$ & $\ldots$ \\
\hline Baseline cancer characteristics & & \\
\hline ED vs. LD & $2.99[2.44-3.67]$ & $2.69[2.18-3.33]$ \\
\hline \multicolumn{3}{|l|}{ Paraneoplastic syndrome } \\
\hline - None & 1 & $\ldots$ \\
\hline - Endocrine & $1.57[1.20-2.06]$ & $\ldots$ \\
\hline - Other & $0.74[0.33-1.65]$ & $\ldots$ \\
\hline Etoposide-based CT vs. other CT & $1.27[0.68-2.39]$ & $\ldots$ \\
\hline
\end{tabular}


Table 3. Univariate and Multivariate Analyses of Factors Associated with Mortality from Second-

Line Chemotherapy $(\mathrm{n}=278)^{*}$

\begin{tabular}{|c|c|c|}
\hline & $\begin{array}{l}\text { Univariate } \\
\text { analysis }\end{array}$ & $\begin{array}{l}\text { Multivariate } \\
\text { analysis }\end{array}$ \\
\hline Variable & HR $[95 \% \mathrm{CI}]$ & HR [95\% CI] \\
\hline 2010-2017 vs. 1997-2009 & $0.82[0.64-1.07]$ & $0.97[0.73-1.27]$ \\
\hline \multicolumn{3}{|l|}{ Baseline patient characteristics } \\
\hline Female vs. male & $0.80[0.60-1.05]$ & $\ldots$ \\
\hline Age $>60$ years & $1.01[0.79-1.29]$ & $\ldots$ \\
\hline Cardiovascular comorbidity & $1.08[0.84-1.38]$ & $\ldots$ \\
\hline Respiratory comorbidity & $1.30[0.99-1.71]$ & $\ldots$ \\
\hline Renal comorbidity & $1.12[0.74-1.70]$ & $\ldots$ \\
\hline Hepatic comorbidity & $1.23[0.89-1.69]$ & $\ldots$ \\
\hline \multicolumn{3}{|l|}{ Baseline cancer characteristics } \\
\hline ED vs. LD & $1.81[1.4-2.33]$ & $1.53[1.17-2.01]$ \\
\hline \multicolumn{3}{|l|}{ Paraneoplastic syndrome } \\
\hline - None & 1 & $\ldots$ \\
\hline - Endocrine & $1.54[1.08-2.2]$ & $\ldots$ \\
\hline - Other & $2.74[0.87-8.62]$ & $\ldots$ \\
\hline \multicolumn{3}{|l|}{$1^{\text {st }}$ line characteristics } \\
\hline Mediastinal radiotherapy & $0.53[0.4-0.71]$ & \\
\hline Prophylactic cranial irradiation & $0.59[0.45-0.77]$ & \\
\hline Palliative irradiation & $1.67[1.16-2.41]$ & \\
\hline \multicolumn{3}{|l|}{ Sensitivity (MD, $n=2$ ) } \\
\hline - Sensitive & 1 & 1 \\
\hline - $\quad$ Resistant & $2.14[1.6-2.86]$ & $1.67[1.19-2.35]$ \\
\hline - Refractory & $2.77[1.99-3.85]$ & $1.74[1.17-2.61]$ \\
\hline \multicolumn{3}{|l|}{$2^{\text {nd }}$ line characteristics } \\
\hline \multicolumn{3}{|l|}{$2^{\text {nd }}$ line CT } \\
\hline - Etoposide & 1 & 1 \\
\hline - Taxane & $2.61[2.00-3.41]$ & $1.54[1.10-2.16]$ \\
\hline - Other & $1.69[1.20-2.56]$ & $1.09[0.67-1.76]$ \\
\hline
\end{tabular}

*One patient with unknown date of second line start was excluded.

CT, chemotherapy; ED, extensive disease; LD, limited disease; MD, missing data. 